\title{
Facebook-Assisted Communication in EFL Learning: A Case Study of UHD Students of English
}

\author{
Sahima Abdulsalam Bdaiwi \\ Department of English Language and Literature \\ University of Human Development \\ Sulaimaniyah, Iraq \\ sahima.bdaiwi@uhd.edu.iq \\ ORCID iD:0000-0003-4172-8869 \\ Assistant Lecturer in the department of English Language, and head of Quality Assurance Committee in the
}

college of Languages. I have three published research papers in the field of English Language.

\begin{abstract}
- this research paper investigates the influences of social networks on the improvement of communication skills among EFL learners. The paper considers the new forms of social networks like Facebook and Skype as new effective mediums for the process of Language Learning that help EFL learners to improve their communication capacity. Since, social networks take a major part in our daily life, and play a crucial role in our development in term of knowledge and information; therefore, they can be integrated and involved in the process of Language Learning because they can provide a better environment and interaction between teachers and learners compared to the traditional classes. So, learners in social network-assisted language learning will be able to accelerate and improve their abilities in term of listening, speaking, and writing skills. Thus, the focus of this paper will be on Facebook as a popular social network that can improve communication skills among EFL learners. To theorize this argument, an experimental study was conducted with the participation of 40 freshmen from University of Human Development in KRG who were taking conversation class in the department of English Language. The students were divided into for two different groups; group A (20 students) as the experimental group, and group B (20 students) as the control group. The investigation consisted of three months of study and observation with two different tests. First of all, an entrance test was conducted for the two groups from the very beginning of the language course to measure the students' communication skills before their entrance in the course. Then, the two groups were allowed to participate in two different English Language courses; a traditional English Language course inside class for the control group, and a Facebook-assisted English language course for the experimental group. At the end of the language courses, a posttest was conducted to measure the amount of improvement the students made in their communication skills during the threemonth language course. The results showed significant improvement in the communication capacity of the students who participated in the Facebook-assisted English language course, while little improvement observed among the students who participated in the traditional English Language course.
\end{abstract}

Keywords-component; Social networks, Facebook, Language learning, communication skills

\section{Introduction}

Nowadays, education is considered as one of the sections that were affected by the technological advancement, and this affection can be observed in the fields of science, medicine, and space. Therefore, most of the universities are considering the different forms of technology as basic tools for the learning process because they allow learners to have access to a variety of choices to get knowledge and information, and at the same time, give them free time and space to share their ideas with people away from them. So, this new environment creates a kind of virtual interaction between learners and teachers that helps the learners to gain more knowledge and skills.

In this way, language learning centers, as well as language departments in the universities started to involve their learners and students in the forms of technology to help them get the target language effectively in a short period of time. The forms of technology that are introduced to language learners to facilitate the learning process are: Data projector, DVD Players, Computers, and Sound Recorders. Thus, it seems that a kind of change is happening in the traditional form of teaching foreign languages. Krashen (1982:10) commented on this change in the process of language learning by stating that "learning a language requires getting beyond textbooks"; teachers and learners should no longer rely on books and the classical way of teaching, but they should listen to music, use computer programs, and watch movies in the target language so as to create a proper environment that helps their learning process.

In this field, social networks are the latest forms of technology that can provide an alternative environment for EFL learners to get the language away from the structure of the traditional classes. These forms can contribute the process of language learning in the shape of websites like Facebook or in the shape of applications like Skype. In this research paper, the concentration will be on Facebook in order to show and theorize the impact of this form on the 
communication skills of EFL learners. So, the paper tries to answer the following questions:

1-What are the influences of Facebook on communication skills?

2-How Facebook improves communication capacity among EFL learners?

\section{Literature Review \& the Main Concepts:}

From the past two decades, computers assisted the process of language learning in different forms so as to support the development of learners' language skills. A lot of researches have been done in this field in order to make a reform in the classical way of teaching languages. In 2004, another form of technology came to us in the shape of a social networking site which was called Facebook to invade our daily life. This form of technology is capable of connecting people with each other from different countries with different languages in order to share their thoughts, express their feelings, and take argumentative stances.

The impact of this social network is so huge on people that no one is ready to ignore it easily for a week. According to a research by Monica-Ariana as he cited from Nielsen (2009), "In the U.S alone, total minutes spent on social networking sites has increased 83 percent year- over- year. In fact, total minutes spent on Facebook increased nearly 700 percent year- over- year, growing from 1.7 billion minutes in April 2008 to 13.9 billion in April 2009, making it No. 1 social networking site for the month"(122). Therefore, Facebook became the most reliable source of knowledge, news updates, and information for people around the world. Facebook is not only influencing people physically, but in rather, influencing their languages as well. From a linguistic perspective, the influences of Facebook can be observed through the appearance of new words like "news feed, viral, hashtag, wiki- just to randomly pick somewhich did not make any sense few years ago, or meant something completely different than they do nowadays" (Monica-Ariana 122). In this way, undeliberate change is going on in English language due to the forms of technology like Facebook.

\section{Social Networks and their Impact on Language Learning}

Popularity of social networks among people can be invested in the field of language learning as they allow their users to have live contact with people around the world. The importance of using social networks can be traced back to the interaction between input and output in the process of Language learning. If learners could not convert the outputs of their teachers into inputs, then, the learning process stops. Therefore, teachers should try to produce comprehensible output as much as possible to help their learners to convert the received outputs into inputs. Sometimes, the condition of the learners, and their anxieties inside the class are reasons behind the collapse of input and output interaction.

Anxieties inside class also prevent learners from involving, and participating in discussions. Therefore, social networks like Facebook can be used to solve this problem through providing a mobile class that can be attended at the time and place that learners prefer. Ahlqvist quoted from Pope Anamaria Mirabela, as he commented on this issue by stating that "the impact of social network relies on the fact that they employ mobile and web-based technologies to create highly interactive platforms via which individuals and communities share, create, and co-create, discuss, and modify, user generated content" (Ahlqvist, 2008). In this way, computer assisted language learning can get rid of the class anxieties through providing individualized or online teaching.

Thus, the addition of social networks to the process of language learning helps teachers to make their outputs be more comprehensible to their learners. This way, learners are obliged to participate, share their ideas, and thereby, get the lessons properly. There is a Chinese proverb that embeds the above argument, which says, "Tell me, I'll forget. Show me, I'll remember. Involve me, I'll understand". Thus, social networks like Facebook can become an authentic medium for language learning that assists "language learners who are restricted because of some barriers such as age, economic problems, age, and gender,..." to get the language at home via Facebook (Derakhshan and Samareh, 2015:p.1092).

\section{Communication skills and Facebook}

Usually, communication is one of the obstacles that prevent a language learner from improving his language skills. Sometimes learners can master Grammar and rules of English language perfectly, but still they cannot communicate, while there are learners or non-natives who are speaking English language fluently, although they don't have anything concerning English Grammar. So, this gives us an idea that Learning English language should go beyond Grammar and rules. The basic element in language learning is communication. Once a student starts to communicate, gradually he can master English rules and Grammar. Therefore, Grammar should be extracted from the basic levels of English Language course, and concentrate on the communication skills of learners that were ignored. Roberts comments on the ignorance of communication in Language teaching by stating that "the Communicative Approach in Language teaching in its original sense has long been theoretically dead, it has for an almost equally long time at least potentially existed in a new form, and continues to thrive" $(2004,1)$. Keaten states that communication is frequently cited as a "factor that contributes to an individual's unwillingness to communicate, in both in L1 and ESL contexts" (Keaten, 2000).

Sometimes the lack of opportunities in the structure of the traditional classes is reason behind the active participation of learners, and their unwillingness to communicate. Zhou Nan quoted from Liu and Littlewood (1997) as they support this argument by stating that: Students' English communication
confidence and oral English proficiency
are affected by the frequency of 
opportunities to speak English. The more students speak English, the more confidence they are in their own English speaking competence and vice versa. For some students, speaking in front of a group is a high risky behavior, especially when they are not confident in their English. Many students choose to avoid oral participation, which they perceive as uncertain, in case they lose face or make fool of themselves (12).

To overcome these barriers in front of EFL learners, social networks like Facebook can be used to provide a combination of different forms of technology like audio, video, picture, animation, and writing. These forms together can be considered as a starting point for learners who have difficulties with the traditional class anxieties. This way, classes no longer exist, and at the same time, books and teachers no longer are the source of knowledge. Derakhshan who quoted form Kroonberg (1995) claim that "language learners who were shy and lacked confidence in speaking in class can express themselves by using computer media. Certainly these learners become motivated to participate in future discussions on the same topics" (1092).

According to Al-Sofi (2016:93), online communication can play an important role in developing listening and speaking skills that can be enhanced through authentic materials, and audio and videoconferencing in social networking in general. Therefore, Facebook as a social network can overcome EFL learners' shyness and anxieties in class, because learners in Facebook assisted language learning have more opportunity to communicate. A learner in a traditional class may feel shy to involve and participate in front of his classmates, while in Facebook-assisted language course, he is alone, he is the one who speaks, and gradually, he will be more self-confident. So, the opportunity of having individual teaching can be obtained through Facebook easily, and any discussion within the lessons will accrue between the learner and the teacher. In addition to that, video conferencing unit can be added to involve more students in the discussions. This way, a virtual class from Facebook that allows learners to have group-work and speak to each other substitutes the traditional classes.

After the virtual classes of Facebook, learners still can go on with the process of language learning, as they can contact with native speakers to improve their communication and writing skills. Facebook can support the two types of communication; oral communication, and written communication. Oral communication is the main part that Facebook can support through video chat between learners and teachers, and written communication can also be improved through the chats between learners and their teachers. In this way, the learners get feedback about their mistakes from the natives that help them to improve their writing skills (Levy, 775). Although they cannot learn academic writing skills, but at least they can enhance their grammar and vocabulary as well as their spelling. In addition to this, there is an application that can be added to Facebook chatting which is called "Grammarly" that checks learners grammatical and spelling mistakes. This program can function as a teacher for the learners, while the teacher is offline.

To practically answer the research questions of this paper, and further prove the impact of Facebook on communication skills among EFL learners, this paper conducted an experimental study on 40 EFL learners to statistically demonstrate the improvement communication skills among the learners after the study. In this way, the research can become a turning point for the process of language learning, as it adds an updated tool for learners to improve their communication skills.

\section{Methods:}

\section{A. Participants:}

For this study, 40 freshmen as EFL learners were randomly selected form University of Human Development in KRG. The learners were first year students who were taking conversation class in the department of English language in the academic year 2014-2015. The age of the students were between 18 to 20 years old. 20 of the students were males, while the other 20 students were females.

\section{B. Techniques:}

The selected students were divided up into two groups; the experimental group (A), and the control group (B). Each group consisted of 20 students; 10 males, and 10 females. Then, an ordinary English language course was given to the groups, but in two different forms. A traditional English language course for group B (the control group), and a Facebook assisted English language course for group A (the experimental group). Before the courses started, the students had participated in an entrance test to measure their communication skills before the course, and then, they participated in the courses that lasted for three months. After the three months, the students participated in a post-test to measure the improvement in their communication skills.

\section{Procedures:}

The paper applied action research in order to investigate the impact of Facebook on communication skills among EFL learners. Action research is used because it reflects the method that helps teachers and researchers to examine, and explore aspects in language learning in order to take action and make improvement in both their practice and their students' learning outcomes (Taylor, 2002).

The study started in the beginning of the first semester of the academic year 2014-2015. The entrance test was conducted on 1st of November 2015 for the 40 students. The students were not informed that they are participating in a research with this aim, and they were tested individually through interviews to measure their communication skills. 
They were given pictures, authentic materials, and ideas to talk about so as to measure their oral communication, and concerning their written communication, they were asked questions on paper sheets so as to test their spelling and accuracy in writing. The criteria of the tests were taken from some international speaking and writing skills like IELTS and TOEFL (iBT), but with changes to suit the level of the participants. The below table shows the criteria of the entrance test:

\section{TABLE I}

\begin{tabular}{|l|l|l|}
\hline \multicolumn{2}{|l|}{ Entrance Test } & \\
\hline No & Criteria & Marks \\
\hline 1 & Insightfulness (Understanding) & 10 \\
\hline 2 & Self-confidence & 10 \\
\hline 3 & Accuracy & 10 \\
\hline 4 & Critical Thinking & 10 \\
\hline 5 & Fluency & 10 \\
\hline 6 & Confusion & 10 \\
\hline 7 & Spelling Mistakes & 10 \\
\hline 8 & Conflict & 10 \\
\hline 9 & Structure of the sentences & 10 \\
\hline 10 & $\begin{array}{l}\text { Emotional Management } \\
\text { (Controlling emotions in speaking) }\end{array}$ & 10 \\
\hline & & 100 \\
\hline
\end{tabular}

After the entrance, the two groups participated in two different language courses for three months at University of Human Development / Department of English Language and Literature. Group B (the control group) participated in a traditional language course inside class, and group A (the experimental group) participated in an online language course via Facebook video chat, and video conferencing service. Then, after the three months of Language course, the two groups participated in a post-test to measure the improvement they have made in their communication skills. The criteria for the post-test were the same criteria of the pre-test. This way, through comparing the results of the two tests, one can notice the changes that happened in the communication capacity of each student, but for analyzing the collected data of the two tests, the paper consulted some of the calculations of One-Way ANOVA in SPSS calculator to give a clear picture of the improvement made among EFL learners in term of communication skills.

\section{Results:}

At the end of the language courses, the collected data were analyzed for the two groups. First of all, the results of the pre-test showed that the average of the students is almost the same, which indicates the similarity between the levels of the 40 students who participated in the research. The mean of the experimental group before the English Language course was (\%44), while the mean for the control group before that course was (\%45). But in the post-test, significant changes can be observed. Students of the 645 experimental group who participated in the online course could raise their average from (\%44) to (\%71), while students of the control group, could not make much improvement, although they could raise their average from (\%45) to (\%59). In this way the percentage of improvement in communication skills for the experimental group would be (\%27), while the same percentage for the control group would be (\%14). So, the variance of improvement in communication skills for the two groups would be (\%11). These statistical analyses can be seen clearly in Table II, III, and IV.

TABLE II

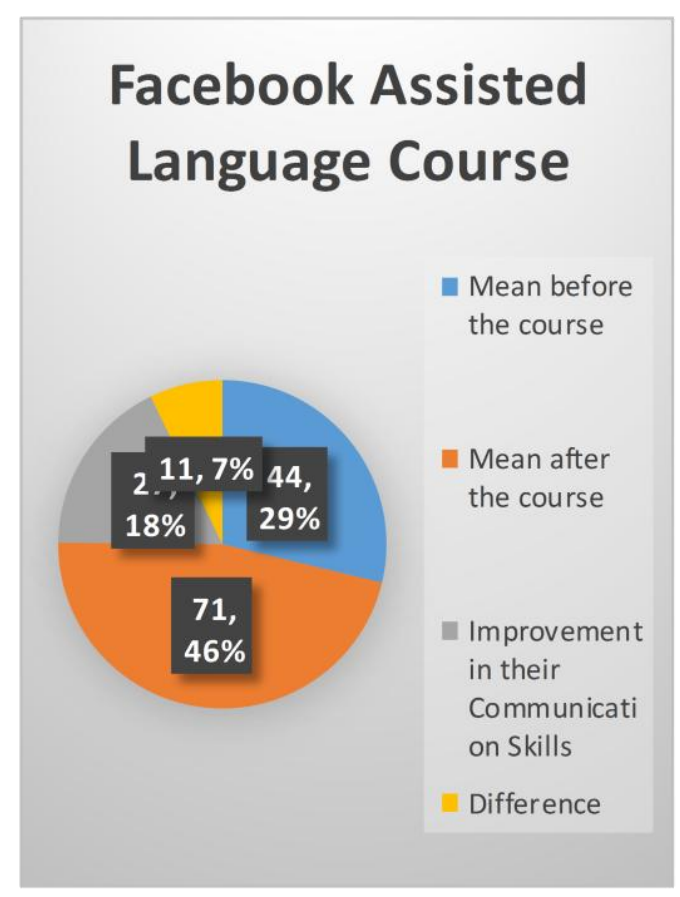

TABLE III

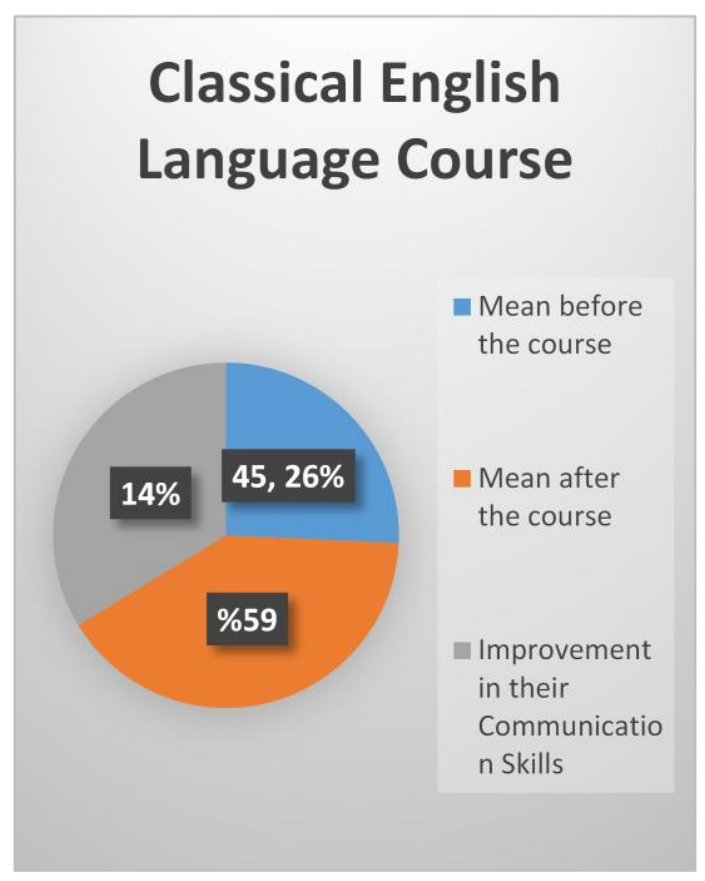


JUHD / Vol. 3, No. 3, August 2017: pp 642-647

e-ISSN: 2411-7757, p-ISSN 2411-7765

\begin{tabular}{|c|c|c|c|c|c|c|c|c|c|c|c|}
\hline \multirow{7}{*}{ No. } & \multirow{7}{*}{ Name } & \multirow{7}{*}{$\begin{array}{l}\dot{\bar{\theta}} \\
\stackrel{0}{0} \\
\stackrel{0}{0}\end{array}$} & \multirow{7}{*}{ 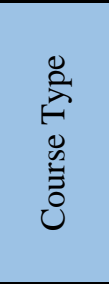 } & \multirow{7}{*}{ Tests } & \multirow{7}{*}{ 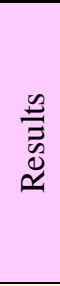 } & & & & & Post-test & 61 \\
\hline & & & & & & \multirow{2}{*}{27} & \multirow{2}{*}{ Student 27} & \multirow{2}{*}{ M } & \multirow{2}{*}{ Classic } & Pre-test & 45 \\
\hline & & & & & & & & & & Post-test & 59 \\
\hline & & & & & & \multirow{2}{*}{28} & \multirow{2}{*}{ Student 28} & \multirow{2}{*}{$\mathrm{F}$} & \multirow{2}{*}{ Classic } & Pre-test & 51 \\
\hline & & & & & & & & & & Post-test & 65 \\
\hline & & & & & & \multirow{2}{*}{29} & \multirow{2}{*}{ Student 29} & \multirow{2}{*}{ M } & \multirow{2}{*}{ Classic } & Pre-test & 48 \\
\hline & & & & & & & & & & Post-test & 62 \\
\hline \multirow{2}{*}{1} & \multirow{2}{*}{ Student1 } & \multirow{2}{*}{ M } & \multirow{2}{*}{ Online } & Pre-test & 40 & \multirow{2}{*}{30} & \multirow{2}{*}{ Student30 } & \multirow{2}{*}{$\mathrm{F}$} & \multirow{2}{*}{ Classic } & Pre-test & 50 \\
\hline & & & & Post-test & 69 & & & & & Post-test & 69 \\
\hline \multirow{2}{*}{2} & \multirow{2}{*}{ Student 2} & \multirow{2}{*}{ F } & Online & Pre-test & 38 & & & & & Pre-test & 40 \\
\hline & & & & Post-test & 67 & 31 & Student31 & $\mathrm{M}$ & Classic & Post-test & 62 \\
\hline 3 & Student 3 & $M$ & Online & Pre-test & 40 & & & & & Pre-test & 40 \\
\hline & & & & Post-test & 75 & 32 & Student32 & $\mathrm{F}$ & Classic & Post-test & 54 \\
\hline 4 & Student 4 & $\mathrm{~F}$ & Online & Pre-test & 40 & & & & & Pre-test & 44 \\
\hline & & & & Post-test & 69 & 33 & Student33 & $\mathrm{M}$ & Classic & Post-test & 58 \\
\hline 5 & Student 5 & $M$ & Online & Pre-test & 44 & & & & & Pre-test & 47 \\
\hline & & & & Post-test & 68 & 34 & Student34 & $\mathrm{F}$ & Classic & Post-test & 74 \\
\hline 6 & Student 6 & $\mathrm{~F}$ & Online & Pre-test & 42 & & & & & Pre-test & 43 \\
\hline & & & & Post-test & 71 & 35 & Student35 & M & Classic & Post-test & 61 \\
\hline 7 & Student 7 & M & Online & Pre-test & 43 & & & & & Pre-test & 45 \\
\hline & & & & Post-test & 62 & 36 & Student36 & $\mathrm{F}$ & Classic & Post-test & 53 \\
\hline 8 & Student 8 & $\mathrm{~F}$ & Online & Pre-test & 49 & & & & & Pre-test & 45 \\
\hline & & $\Gamma$ & Uimine & Post-test & 76 & 37 & Student37 & M & Classic & Post-test & 54 \\
\hline 9 & Student 9 & M & Online & Pre-test & 49 & & & & & Pre-test & 54 \\
\hline 9 & Student 9 & $M$ & Unline & Post-test & 74 & 38 & Student38 & $\mathrm{F}$ & Classic & Post-test & 79 \\
\hline 10 & Student10 & $\mathrm{F}$ & Online & Pre-test & 54 & & & & & Pre-test & 54 \\
\hline & & $\Gamma$ & Uimine & Post-test & 79 & 39 & Student39 & M & Classic & Post-test & 63 \\
\hline 11 & Student11 & M & Online & Pre-test & 38 & & & & & Pre-test & 49 \\
\hline 11 & studemili & NV & Uiminte & Post-test & 66 & 40 & Student40 & $\mathrm{F}$ & Classic & Post-test & 58 \\
\hline
\end{tabular}

\begin{tabular}{|c|c|c|c|c|c|}
\hline \multirow{3}{*}{12} & \multirow{3}{*}{ Student 12} & & & & \\
\hline & & \multirow{2}{*}{$\mathrm{F}$} & \multirow{2}{*}{ Online } & Pre-test & 38 \\
\hline & & & & Post-test & 65 \\
\hline \multirow{2}{*}{13} & \multirow{2}{*}{ Student13 } & \multirow{2}{*}{ M } & \multirow{2}{*}{ Online } & Pre-test & 42 \\
\hline & & & & Post-test & 76 \\
\hline \multirow{2}{*}{14} & \multirow{2}{*}{ Student14 } & \multirow{2}{*}{$\mathrm{F}$} & \multirow{2}{*}{ Online } & Pre-test & 43 \\
\hline & & & & Post-test & 69 \\
\hline \multirow{2}{*}{15} & \multirow{2}{*}{ Student15 } & \multirow{2}{*}{ M } & \multirow{2}{*}{ Online } & Pre-test & 46 \\
\hline & & & & Post-test & 70 \\
\hline \multirow{2}{*}{16} & \multirow{2}{*}{ Student 16} & \multirow{2}{*}{$\mathrm{F}$} & \multirow{2}{*}{ Online } & Pre-test & 43 \\
\hline & & & & Post-test & 74 \\
\hline \multirow{2}{*}{17} & \multirow{2}{*}{ Student17 } & \multirow{2}{*}{ M } & \multirow{2}{*}{ Online } & Pre-test & 47 \\
\hline & & & & Post-test & 69 \\
\hline \multirow{2}{*}{17} & \multirow{2}{*}{ Student 18} & \multirow{2}{*}{$\mathrm{F}$} & \multirow{2}{*}{ Online } & Pre-test & 52 \\
\hline & & & & Post-test & 75 \\
\hline \multirow{2}{*}{19} & \multirow{2}{*}{ Student19 } & \multirow{2}{*}{ M } & Online & Pre-test & 50 \\
\hline & & & & Post-test & 70 \\
\hline 20 & Student20 & $\mathrm{F}$ & Online & Pre-test & 51 \\
\hline & & & & Post-test & 75 \\
\hline 21 & Student21 & $\mathrm{M}$ & Classic & Pre-test & 40 \\
\hline & & & & Post-test & 44 \\
\hline 22 & Student22 & $\mathrm{F}$ & Classic & Pre-test & 40 \\
\hline & & & & Post-test & 46 \\
\hline 23 & Student23 & $\mathrm{M}$ & Classic & Pre-test & 42 \\
\hline $2 J$ & studentilz & & Classic & Post-test & 52 \\
\hline 24 & Student 24 & $\mathrm{~F}$ & Classic & Pre-test & 39 \\
\hline 24 & Studentile & & & Post-test & 53 \\
\hline 25 & Student 25 & $\mathrm{M}$ & Classic & Pre-test & 43 \\
\hline & & & & Post-test & 57 \\
\hline 26 & Student 26 & $\mathrm{~F}$ & Classic & Pre-test & 47 \\
\hline
\end{tabular}

From the above tables, it becomes clear that significant changes have happened in the communication skills of the students who participated in the Facebook-assisted English language course, and the reason behind this improvement can be related to the opportunities that Facebook offers. First of all, students in the online course had more chance to talk than the students of the control group, and then, they could get individualized teaching, face to face via Facebook video chat with their teachers, while students of the control group could not get this opportunity. Since the online students could participate in the language course in the time and place they prefer; therefore, they could get rid of the class anxieties and boredom.

According to the results, the students who participated in the Facebook-assisted language course could raise their communication ability because they no longer showed any shyness to participate, but in rather, they could control their emotions, and participate in the argumentative stances. They got a kind of self-confidence to speak, and they started to chat with their friends and teachers to improve their written communication. Moreover, through their chatting, the students could master their spelling with the help of "Grammarly" application, and at the same time, they could learn how to use words and prepositions.

For the control group, the students participated in the language course in a traditional class. They showed some 
improvement in their communication skills, but compared to the online group, the changes happened cannot be considered significant because the students at the end of the course couldn't get the skills properly. They were unable to express themselves, repeated errors were observed, and they were lacking self-confidence. Thereby, most of the students couldn't control their emotions, while they were speaking. Most of the students had no opportunity to talk to the teacher because of the students' number in the class; thus, they couldn't improve their oral communication skill. For written communication, most of the students couldn't improve this skill as well, because in the traditional language course chatting and spelling are ignored. A teacher alone cannot check the mistakes of 20 students at the same time, and there is nothing called "Grammarly" to automatically check the mistakes. So, at the end, the students couldn't develop this skill properly.

\section{Conclusion:}

This research paper, which examined the impact of Facebook-assisted language learning on communication skills among EFL learners, has proposed that social networks like Facebook should be added to the process of language learning so as to improve EFL learners' communication skills. The paper showed that those students who take language courses via Facebook get self-confidence to speak, they become more motivated, and all of this because of opportunities of participation that Facebook offers. EFL learners in this new instructional tool can get individualized teaching, express their feelings freely, and improve their critical thinking. When learners start to speak in this system, gradually they involve themselves in argumentative stances, and thereby, improve their communication skills. Improvement in oral communication is made through providing opportunities for the learners to speak, while improvement in written communication will be through chatting, and "Grammarly" application. Consequently, Facebook can become an effective medium for EFL learners to overcome one of the obstacles in front of them, which is unwillingness to communication. So, this paper hereby recommends English language teachers to consider this medium in the process of language learning, because students through this medium feel free to speak, get rid of class anxieties, and can improve their skills while the teachers are offline.

\section{- REFERENCES}

A. Drakhshan and S. Hasanabbasi, "Social Networks for Language Learning", Theory and Practice in Language Studies, vol. 5, no. 5, pp. 1090-1095, 2015.

B. Al-Sofi, "The Impact of Online Communication on Learning English: A Case Study of Saudi EFL Learners". International Journal of Applied Linguistics and English Literature ,vol. 5, no. 4, 2016.

J. Keaten, L. Kelly and C. Finch, "Effectiveness of the Penn State Program in Changing Beliefs Associated with Reticence.”, Communication Education, vol. 49, no. 2, pp.134-145,2000.

J. Roberts, "The Communicative Approach to Language Teaching: The King is dead! Long live the King!", International Journal of English Studies, vol. 4, no.1, pp. 1-37, 2004.
L. Chen, "The research on the effects of computer-assisted language learning on English teaching", .2012 $2^{\text {nd }}$ International Conference on Consumer Electronics, Communications and Networks (CECNet) Yichang ,pp.3631-3633,2012.

L. Wang, Y. Qian, M. Scott, G. Chen, and F. K. Soong, Computer-Assisted Audiovisual Language Learning. Computer, vol.45, no. 6. pp 38-47, 2012.

M. Levy, "Technologies in Use for Second Language Learning". The Modern Language Journal, 93, Focus Issue , pp.769-782, 2009.

M. Liu, Reticence, anxiety and performance of Chinese university students in oral English lessons and tests. Ph.D. Thesis, The Chinese University of Hong Kong, 2005.

M. Taylor, Action Research in Workplace Education: A Handbook for Literacy Instructors. Human Resources Development Canada, Hull (Quebec), 2002.

Nan, Zhou. "Communication Research in the EFL Context: Challenges and Directions". Mediterranean Journal of Social Sciences. Vol. 4 (1) January 2013.

N. Kroonenberg, "Developing Communicative and Thinking Skills Via e mail”. TESOL J, vol. 4, no. 2, pp. 24-27, 1995.

N. Liu and ,W. Littlewood, "Why do Many Students Appear Reluctant to Participate in Classroom Learning Discourse?”, System, vol. 25, no.3, pp.371-384, 1997.

S. Krashen, Second Language Acquisition and Second Language Learning. Oxford: Pergamon Press.,1981.

S. Monica- Ariana and P. Anamaria-Mirabela, "The Impact of Social Media on Vocabulary Learning Case Study- Facebook", Annals of the University of Oradea, Economic Science Series, vol.23, no. 2, pp.120-130, 2014.

Social Networking Fact Sheet, December 2013, Paw Research Internet Project, 130 State of the media: The social media report 2009, Featured Insights, Global, Media+Entertainment. Nielsen.socialmedia-report-2012. html retrieved 17.03.2014.

T. Ahlqvist, A. Bäck, M. Halonen and S. Heinonen, (2008). Social media roadmaps exploring the futures triggered by social media, VTT Tiedotteita - Valtion Teknillinen Tutkimuskeskus $\quad$ (2454): 13. www.vtt.fi/inf/pdf/tiedotteet/2008/T2454.pdf retrieved. 20.03. 2014. 